\title{
In vitro production of Sudanese camel (Camelus dromedarius) embryos from epididymal spermatozoa and follicular oocytes of slaughtered animals
}

\author{
A.E. Abdelkhalek ${ }^{1}$, Sh.A. Gabr ${ }^{2}$, W.A. Khalil' ${ }^{1}$, Sh.M. Shamiah ${ }^{3}$, \\ L. Pan ${ }^{4}$, G. Qin ${ }^{4}$, M.H. Farouk,5 \\ ${ }^{1}$ Animal Production Deptartement, Faculty of Agriculture, Mansoura University, Egypt \\ ${ }^{2}$ Animal Production Department, Faculty of Agriculture Tanta University, Egypt \\ ${ }^{3}$ Animal Production Research Institute, Agriculture Research Center, Giza, Egypt \\ ${ }^{4}$ College of Animal Science and Technology, Jilin Agricultural University, Changchun, China \\ ${ }^{5}$ Animal Production Deptartment, Faculty of Agriculture, Al-Azhar University, Nasr City, Cairo, Egypt
}

\begin{abstract}
Application of assisted reproductive technology in camelidea, such as artificial insemination (AI) and embryo transfer, has been slow in comparison to that for other livestock species. In Egypt, there are few attempts to establish in vitro maturation (IVM) and fertilization (IVF) techniques in dromedary camel. The present study was carried out to produce Sudanese camel embryos using in vitro matured oocytes and epididymal spermatozoa. Dromedary camel ovaries were collected from abattoirs and then, the oocytes were aspirated from all the visible follicles on the ovarian surface $(\sim 2-8 \mathrm{~mm}$ in a diameter). Meanwhile, Fetal Dromedary Camel Serum (FDCS) was obtained from camel fetuses after slaughtering. Thereafter, only Cumulus Oocyte Complexes (COCs) were matured in vitro in the Tissue Culture Medium (TCM-199) complemented with 10\% FDCS. Spermatozoa required for in vitro fertilization were collected from testes (epididymal cauda) of the slaughtered camel bulls. The results clearly showed that the maturation rate of oocytes at metaphase II was about $59.5 \%$ while the fertilization rate was around $70.4 \%$. Intriguingly, the embryo rates determined were $13.1 \%$, in 2-cell; $0.0 \%$, in 4 -cell; $34.7 \%$, in $8-16 \%$ cell; $39.1 \%$, in morula and $13.1 \%$ in a blastocyst stage. This study represented a successful in vitro production of Sudanese dromedary camel embryos from epididymal sperm cells and in vitro matured oocytes recovered from slaughtered camels.
\end{abstract}

Key words: blastocyst, cleavage, dromedary camel, epididymal sperm, in vitro maturation, oocytes 


\section{Introduction}

Dromedary camel is one of the most important animals that live in hot, dry or both climates, since it well adapted to the arid conditions. It supports people who live under drastic conditions by diet (milk and meat), in addition to affording precious welfare benefits (fiber, transportation and sports) in these areas (Jianlin 2011).

The in vitro production (IVP) emerged as an effective reproductive approach for cattle species (Gordon 2003). For example, various studies reported the significant effect of the IVP on cattle such as Holstein and Nelore (Batista et al. 2016, Jin et al. 2016). Inconsistent of cattle, dromedary camels are seasonally breed animals (Allam et al. 2013), have a long pregnancy period (13 months), give a single calve every two years (Jianlin 2011). Moreover, Abdalla et al. (2015) reported that camels have a wide range of milk production $(3.5-20 \mathrm{~kg} / \mathrm{d})$. Therefore, it was recommended to make a selection for this species. At a time, people in developing countries slay the camels without caring for their genetic values. Nowadays, the assisted reproductive technologies in camelidae such as artificial insemination (AI) and embryo transfer (ET) are relatively slower in comparison with that of their counterparts of equine, cattle, sheep and goats species (John 2011). This is ascribed to the significant importance of cattle in human livestock feeding relative to camels because they are not geographically distributed in the most advanced countries (Jianlin 2011). There are currently few data available on follicular growth and maturation in camels (Ratto et al. 1999, Kandil et al. 2014). For instance, the in vitro maturation (IVM) and fertilization (IVF) rate of dromedary camel oocytes were investigated under various conditions (Abdoon 2001, Ali and Abdel-Razek 2001, El-Harairy et al. 2007, Zeidan et al. 2015). These studies have revealed that further in vitro production research is needed on dromedary camels. Inspired by this, the present study was carried out to in vitro produce camel embryos upon usage of spermatozoa from epididymal cauda and follicular oocytes which are both recovered from slaughtered Sudanese camel bull and she-camel. Interestingly, the experiments were conducted in non-breeding season, which is highly required for developing countries due to the great importance of camel in their livestock feeding.

\section{Materials and Methods}

This study was jointly planned by the Animal Production Department, Faculty of Agriculture, Man- soura University and Animal Production Research Institute, Dokki, Giza, in cooperation with the Animal Production Department, Faculty of Agriculture, Al-Azhar University, Cairo, Egypt. The study was carried out at the Laboratory of Physiology and Biotechnology belonging to the Animal Production Department, Faculty of Agriculture, Mansoura University. All chemicals and media used in this study were purchased from Sigma (Madrid, Spain) without otherwise specified.

\section{Oocyte collection}

Ovaries were collected from 53 slaughtered Sudanese she-camels with unknown reproductive history in the Elbasatein Abattoir, Cairo, during non-breeding season. Immediately after slaughtering, they were placed in saline solution $(0.9 \% \mathrm{NaCl})$ complemented with antibiotics (100 IU penicillin and 100 $\mu \mathrm{g}$ streptomycin $/ \mathrm{ml}$ ) at about $25^{\circ} \mathrm{C}$ and transported to the laboratory. Thereafter, the redundant tissues were cut from the ovarian stalk and the ovaries were washed three times using Phosphate Buffer Solution (PBS) at $28^{\circ} \mathrm{C}$, added to $2 \mathrm{mg} / \mathrm{ml}$ of Bovine Serum Albumin (BSA), $100 \mathrm{IU}$ penicillin and $100 \mu \mathrm{g}$ streptomycin/ml to eliminate adhering tissues or blood clot. Then, the ovaries were washed one-time using ethanol $70 \%$ to discard any contamination and the oocytes were collected by aspiration using a 20-gauge hypodermic needle linked to a sterile disposable $5 \mathrm{ml}$ syringe containing $2 \mathrm{ml}$ PBS as harvesting medium (Pavlok et al. 1992). After aspiration, the syringe contents were slowly dispelled into sterile Petri dish $(60 \mathrm{~mm})$ for searching oocytes under a stereo-microscope. The oocytes collected were washed three times in PBS, evaluated under an inverted microscope and classified into compact oocytes with $\geq 5$ layers of complete cumulus cells and evenly granulated dark ooplasm (COCs), partial denuded, denuded, shrunken and fragment oocytes (Madison et al. 1992). Only, COCs were used for in vitro maturation.

\section{In vitro oocyte maturation (IVM)}

The basal maturation medium (BMM) used in this study was TCM199 as a liquid medium (Egyptian Organization of Biological Products and Vaccine, Giza), supplemented with $10 \%$ (v/v) Fetal Dromedary Camel Serum (FDCS), $10 \mu \mathrm{g} / \mathrm{ml}$ FSH, $10 \mathrm{IU} / \mathrm{ml}$ hCG (Pregnyl, Nile, Co. for Pharm. Cairo, ARE), estradiol (E-17 $\beta$ ), $20 \mathrm{mMol}$ Na Pyruvate, 100 IU/ml Na Penicillin $\mathrm{G}$ and $100 \mu \mathrm{g} / \mathrm{ml}$ Streptomycin. About $200 \mu \mathrm{l}$ from prepared BMM was placed into a sterile Petri 
dish $(60 \mathrm{~mm})$, covered by sterile mineral oil, then Petri dishes were incubated in $\mathrm{CO}_{2}$ incubator $(5 \%$ $\left.\mathrm{CO}_{2}\right)$ at $38.5^{\circ} \mathrm{C}$ and high humidity (90-95\%) for at least $1 \mathrm{~h}$ for equilibration before placing oocytes in culture dish. BMM was adjusted to $\mathrm{pH}$ value from 7.2 to 7.4 and osmolarity from 280 to $300 \mathrm{mOsmol} / \mathrm{kg}$, and filtered by $0.22 \mu \mathrm{m}$ millipore filter (Milieux GV, millepore, Cooperation Bedford, MOA).

To prepare FDCS, blood samples were collected from three camel fetuses immediately after slaughtering pregnant dromedary she-camels through the umbilical cord puncture into $15 \mathrm{ml}$ centrifuge tube and placed into an ice box, then transported to the laboratory within 3-4 h. Blood samples were centrifuged two times at $2800 \mathrm{xg}$ for $15 \mathrm{~min}$ to aspirate clear serum by a pasture pipette which was placed in other $15 \mathrm{ml}$ sterile centrifuge tubes transferred in a water bath at $56^{\circ} \mathrm{C}$ for $30 \mathrm{~min}$ and left to cool for obtaining heat-inactivated serum. Thereafter, the serum was placed into $1.5 \mathrm{ml}$ Eppendorf tubes and frozen until usage.

Only COCs which presented a compact, non-atretic cumulus oophorus-corona radiata and an oocyte with homogeneous cytoplasm were selected for in vitro maturation. All selected COCs were washed thoroughly three times in the collection medium and two times in BMM to remove substances from the follicular fluid which may hinder maturation. Then, about 25-30 oocytes per droplet were placed by a pasture pipette in petri dishes containing the maturation medium. Petri dishes containing oocytes and BMM were incubated in a carbon dioxide incubator $(5 \%$ $\mathrm{CO}_{2}$ ) at $38.5^{\circ} \mathrm{C}$ and high humidity for $40 \mathrm{~h}$. At the end of the maturation time, COCs were fixed and stained. COCs were placed in PBS containing hyaluronidase $(1 \mathrm{mg} / \mathrm{ml})$. The oocytes were then pipetted onto a slide. A cover slip, spotted with a paraffin wax-vaseline (10:1) mixture at each corner, was placed directly over the center of the drop containing the oocytes. Oocytes were fixed by placing the slides in acetic acid: ethanol (1:3) for overnight, and stained with a drop of aceto-orcein (1\% orcein in $60 \%$ acetic acid $\mathrm{w} / \mathrm{v})$ for 4-5 min, and then washed by aceto-glycerol (3:1). Estimation of nuclear maturation was carried out under a phase contrast microscope using $\times 200$ and $\times 500$ magnification, and expressed as the percentage of oocytes arrested at the metaphase II.

\section{Collection of epididymal spermatozoa}

Testes of 3 mature camel bulls were collected from the same abattoir of ovaries collection. The testes were collected immediately after slaughtering, placed in plastic bags in an icebox $\left(5^{\circ} \mathrm{C}\right)$ and trans- ported to the laboratory within about 3-4 h. Each testicle was isolated from its tunica vaginalis and other attached extraneous tissues, washed 3 times using tap water and finally washed using ethyl alcohol $70 \%$. Different incisions in the tail of the epididymis were performed with a scalpel and then, by pressing that region manually the epididymal spermatozoa were released and collected by aspiration with sterile disposable syringe $(5 \mathrm{ml})$ containing $2 \mathrm{ml}$ PBS as an extender (Deen et al. 2003). The epididymal spermatozoa collected were examined under a low power microscope using a hot stage adjusted at $37^{\circ} \mathrm{C}$. Initial motility was estimated and only samples with $\geq 60 \%$ initial motility were used.

\section{In vitro fertilization (IVF)}

The collected epididymal spermatozoa in PBS were washed three times using TALP medium (Tyrod's Albumin Lactate Pyruvate) (Parrish et al. 1986) by centrifugation at $2000 \mathrm{xg}$ for $10 \mathrm{~min}$ each time. The washed sperm samples were diluted with fertilization medium (TALP, Tyrod's Albumin Lactate Pyruvate) supplemented with $100 \mathrm{IU} / \mathrm{ml}$ Penicillin, $4 \mathrm{mg} / \mathrm{ml} \mathrm{BSA,} 100 \mu \mathrm{g} / \mathrm{ml}$ Streptomycin and 10 $\mu \mathrm{g} / \mathrm{ml}$ heparin (capacitated substance) up to the final concentration of about $50 \times 10^{6} \mathrm{sperm} / \mathrm{ml}$ (determined by haemocytometer) and allowed to swim up for $1 \mathrm{~h}$ in an incubator $\left(5 \% \mathrm{CO}_{2}\right.$ and $\left.38.5^{\circ} \mathrm{C}\right)$ at an angle of $45^{\circ}$. The in vitro matured oocytes were washed twice in the fertilization medium and randomly distributed to 4-well culture plates (40-50 COCs/well) containing $490 \mu \mathrm{L}$ of the fertilization medium. Whereas, the motile spermatozoa $(10 \mu \mathrm{L})$ were added to the oocytes in the fertilization medium at the condensation of approximately $1 \times 10^{6} / \mathrm{mL}$. Both sperms and oocytes were co-incubated at $38.5^{\circ} \mathrm{C}$ in a moist atmosphere of $5 \%$ $\mathrm{CO}_{2}$ in air for $24 \mathrm{~h}$.

\section{In vitro culture}

After fertilization period $(24 \mathrm{~h})$, the presumptive zygotes were removed from the fertilization medium, washed three times in an embryo culture medium consisting of TCM199 supplemented with $100 \mathrm{IU} / \mathrm{ml}$ penicillin, $100 \mu \mathrm{g} / \mathrm{ml}$ Streptomycin and $10 \%$ FDCS. Thereafter, the fertilized oocytes were cultured in 500 $\mu l$ of the culture medium in 4-well dishes covered by sterile mineral oil and incubated in a carbon dioxide incubator at $38.5^{\circ} \mathrm{C}$ in a moist atmosphere of $5 \% \mathrm{CO}_{2}$ in air for 7 days. The culture medium was renewed by a fresh medium every $48 \mathrm{~h}$. The first cleavage was recorded on day 2 , whereas development to blastocyst 
Table 1. Percentages of camel follicular oocytes at different phases in vitro post maturation.

\begin{tabular}{|c|c|c|}
\hline Oocyte phase & $\mathrm{N}$ & $\%$ \\
\hline Germinal vesicles $(\mathrm{GV})$ & 23 & 15.0 \\
\hline Germinal vesicles breakdown (GVB) & 8 & 5.2 \\
\hline Metaphase I (MI) & 8 & 5.2 \\
\hline Metaphase II (MII) & 91 & 59.5 \\
\hline Degenerated oocytes & 23 & 15.1 \\
\hline Total oocytes & 153 & 100 \\
\hline
\end{tabular}

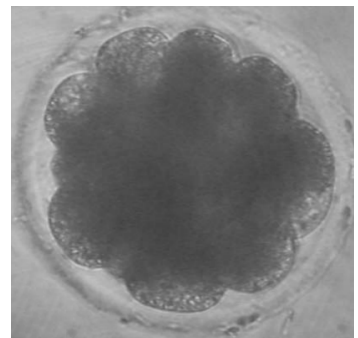

Plate 1. Embryo at morula stage.

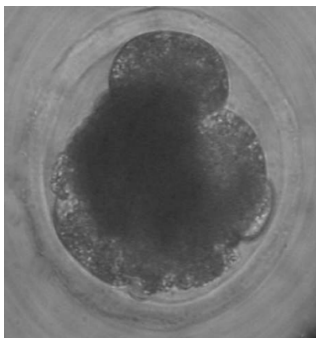

Plate 2. Embryo at 8-16 cell stage.

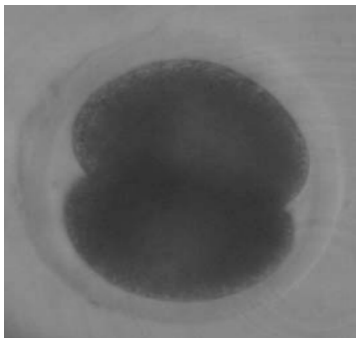

Plate 3. Embryo at 2-cell stage.

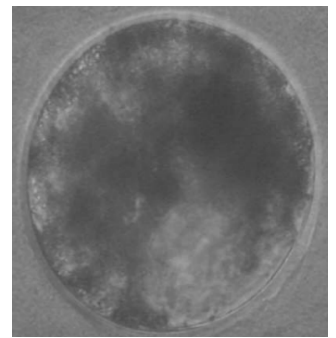

Plate 4. Embryo at early blastocyst stage

Table 2. Fertilization rate of in vitro matured oocytes and embryonic stages of in vitro development of camel embryos.

\begin{tabular}{|c|c|}
\hline Item & $\mathrm{N}$ \\
\hline $\begin{array}{l}\text { In vitro fertilization: } \\
\text { Total oocytes* } \\
\text { Mature oocytes** } \\
\text { Unfertilized oocytes } \\
\text { Fertilized oocytes } \\
\text { Fertilization rate, \% }{ }^{(1)} \\
\text { Fertilization rate, \% } \\
\text { (2) }\end{array}$ & $\begin{array}{c}165 \\
98 \\
67 \\
69 \\
41.8 \\
70.4 \\
\end{array}$ \\
\hline $\begin{array}{l}\text { Embryonic stage }{ }^{* * *}: \\
2 \text { cell } \\
4 \text { cell } \\
8-16 \text { cell } \\
\text { Morula } \\
\text { Early blastocyst }\end{array}$ & $\begin{array}{c}9(13.1 \%) \\
- \\
24(34.7 \%) \\
27(39.1 \%) \\
9(13.1 \%)\end{array}$ \\
\hline
\end{tabular}

* Immature oocytes, ** Calculation based on maturation rate $(59.5 \%),{ }^{* *}$ Based on the number of fertilized oocytes, ${ }^{(1)}$ : Based on the total number of oocytes, ${ }^{(2)}$ : Based on the calculated number of in vitro mature oocytes.

stage was recorded on days 4-7 of culture using inverted microscope. The fertilized oocytes were examined after fertilization under an inverted microscope to determine the cleavage rate.

\section{Results}

The results presented in Table 1 showed that the in vitro maturation rate of camel oocytes in term of oocytes parentage arrested at the metaphase II (M II) was $59.5 \%$ in TCM-199 supplemented with $10 \%$ FDCS. Whereas, when the maturation rate included the percentage of oocytes at the metaphase I $(5.2 \%)$, it was increased to $64.7 \%$.

\section{In vitro fertilization}

In the present study, in vitro fertilization rate was $41.8 \%$ based on the total number of immature oocytes, increased to $70.4 \%$ based on a calculated number of in vitro matured oocytes (Table 2). Concerning the embryonic stages of fertilized oocytes, the percentage of embryos at the morula stage (Plate 1) showed the highest frequency distribution of cleaved oocytes $(39.1 \%)$, followed by those at $8-16$ cell stage (Plate 2), while embryos at 2-cell (Plate 3) and blastocyst (Plate 4) stages represented the lowest frequency distribution, amounting to $13.1 \%$ for each. Yet, no embryos at 4-cell stage were detected (Table 2). 


\section{Discussion}

Comparable with the present results, a lower maturation rate (oocytes at M II) for dromedary camel oocytes was recorded (39.3\%, Khalil 2005; $38.4 \%$, Zeidan et al. 2015). In contrast, El-Nahla et al. (2014) showed a maturation rate of $50.2 \%$ using a high-quality oocytes matured in maturation medium supplemented with FSH or eCG hormones during the non-breeding season. However, Torner et al. (2003) showed a maturation rate $(58.5 \%)$ of camel oocytes recovered from the ovaries bearing corpora lutea (CLs) higher than that recovered from non-bearing ovaries $(51.2 \%)$. The ovaries used in this study were taken from camels with anonymous reproductive history (pregnant or non-pregnant) and based upon the previous studies, the wide variation in maturation rate may be related to the time of maturation. This may be explained by the finding of Torner et al. (2003) who reported that the oocytes of pregnant camels require $36 \mathrm{~h}$ of maturation to reach levels of $>50 \% \mathrm{M}$ )) in comparison with the oocytes of non-pregnant camels, where $32 \mathrm{~h}$ are sufficient. Regardless serum supplementation in a maturation medium, in vitro maturation of oocytes depends on several conditions including reproductive status, ages, side of the ovary (Amer and Moosa 2009) and method of oocytes collection (Sansinena et al. 2003, Farag et al. 2012). The last authors found that the ovaries without the corpus luteum are promising subjects for high recovery value of camel oocytes (COCs) which have a great ability to be matured in vitro. In this context, Nagy (2014) declared that TCM-199 medium enhanced the maturation rate of the dromedary camel oocytes more effectively than MEM medium. The higher maturation rate found in this study in comparison to that determined in the most previous studies may revealed the rich constituents of TCM-199 medium which contains numerous nutrients, as inorganic salts, antioxidant, glucose and amino-acids that may enhance follicular activation (Javed et al. 2010). Amino-acids afford energy source molecules and precursor protein synthesis (Fujihara et al. 2012), and antioxidant which is very important for protecting cells against reactive oxygen species (Andrade et al. 2014). In addition, Fetal Dromedary Camel Serum (FDCS) supplementation to the media shows better maturation rate which might be due to the compositions of FDCS serum which is composed of many immunoglobulins of the camel species (El-Hatmi et al. 2006). In comparison with the results dealing with the in vitro maturation rate of camels oocytes, Coleman et al. (2007) showed that the in vitro maturation rate of bovine oocytes matured in TCM-199 supplemented with fetal calve serum amounted to $62 \%$. Whereas, the maturation rate was $53.8 \%$ for buffalo oocytes (Shamiah 2004).

Moreover, in accordance with the present results, Wani et al. (2008) found that the proportion of dromedary camel oocytes fertilized with epididymal spermatozoa was $43 \%$ and those that developed to blastocysts was $14 \%$. Whereas, using freshly ejaculated semen, the rate of cleavage in dromedary camel ranged from 51 to $64 \%$ and the rate of development to blastocyst ranged from $16.5 \%$ to $23 \%$ (Khatir et al. 2005). Moreover, Khatir et al. (2008) found higher cleavage rate $(69 \%)$ with the highest percentage of embryos at blastocyst stage (37\%) when camel oocytes were matured in TCM199 with camel follicular fluid $(2.5 \%)$ obtained from the large follicles. In another species of camel (Lama glama), IVP attained $17 \%$ at blastocysts stage (Conde et al. 2008). Trasorras et al. (2012) found a lower rate of blastocysts reaching 9\%.Recently, blastocyst rate ranged between $34-36 \%$ using TALP culture medium in the same living species (Trasorras et al. 2014). As a result of this, cleavage rate of camel oocytes varies according to the type of culture medium (Khatir et al. 2005), the size of follicle (Khatir et al. 2007) and co-culture with granulosa or oviductal cells (Khatir et al. 2004).

\section{Conclusion}

Based on the results obtained, the present study represents a successful attempt to in vitro production of Sudanese dromedary camel embryo $(39.1 \%$ at morula and $13.1 \%$ at blastocyst stages) from capacitated epididymal sperm cells and follicular oocytes matured in TCM-199 supplemented with $10 \%$ fetal dromedary camel serum. Both sperm cells and oocytes were recovered from slaughtered animals of Sudanese bred. Further investigations are needed for increasing rate of IVP of camels by improving maturation rate with different types of supplements to sera, hormones, temperature and time of maturation period.

\section{Acknowledgements}

The authors acknowledge the International Livestock Management Training Center (ILMTC), Sakha City belonging to the Animal Production Research Institute and the Animal Production Department, Faculty of Agriculture, Mansoura University, Egypt for supporting this study. 


\section{References}

Abdalla EB, Ashmawy AA, Farouk MH, Salama OA, Khalil FA, Seioudy AF (2015) Milk production potential in Maghrebi she-camels. Small Rumin Res 123: 129-135.

Abdoon AS (2001) Factors affecting follicular population, oocyte yield and quality in camels (Camelus dromedarius) ovary with special reference to maturation time in vitro. Anim Reprod Sci 66: 71-79.

Ali A, Abdel-Razek AK (2001) Comparison of number and quality of oocytes in the Egyptian buffaloes (Bubalus bubalis), cows (Bos taurus) and camels (Camelus dromedarius). Assiut Vet Med J 45: 317-325.

Allam WA, Abdalla EB, Zeidan AE, Farouk MH, Abd El-Salaam AM (2013) Morphological and histological changes in the camel testes in relation to semen characteristics during breeding and non-breeding seasons. J Am Sci 9: 74-82.

Amer H, Moosa A (2009) Effect of season and culture media on the competence of dromedary camel oocyte to mature in vitro. Glob Vet 3: 1-8.

Andrade PM, Chaves RN, Alves AM, Rocha R,M Lima LF, Carvalho AA, Rodrigues AP, Campello CC, Gastal EI, Figueiredo JR (2014) Effects of $\alpha$-MEM and TCM-199 culture media and epidermal growth factor on survival and growth of goat and sheep preantral follicles cultured in vitro. Anim Reprod 11: 567-572.

Batista EO, Guerreiro BM, Freitas BG, Silva JC, Vieira LM, Ferreira RM, Rezende RG, Basso AC, Lopes RN, Rennó FP, Souza AH, Baruselli PS (2016) Plasma anti-Mullerian hormone as a predictive endocrine marker to select Bos taurus (Holstein) and Bos indicus (Nelore) calves for in vitro embryo production. Domest Anim Endocrinol 54: 1-9.

Coleman NV, Shagiakhmetova GA, Lebedeva IY, Kuzmina TI, Golubev AK (2007) In vitro maturation and early developmental capacity of bovine oocytes cultured in pure follicular fluid and supplementation with follicular wall. Theriogenology 67: 1053-1059.

Conde PA, Herrera C, Trasorras VL, Giuliano SM, Director A, Miragaya MH, Chaves MG, Sarchi MI, Stivale D, Quintans C, Aguero A, Rutter B, Pasqualini S (2008) In vitro production of llama (Lama glama) embryos by IVF and ICSI with fresh semen. Anim Reprod Sci 109: 298-308.

Deen A, Vyas S, Sahani MS (2003) Semen collection, cryopreservation and artificial insemination in the dromedary camel. Anim Reprod Sci 77: 223-233.

El-Harairy MA, Shamia SM, Abdel-Khalek AE, Khalil WA (2007) Effect of pregnancy status and harvesting technique on recovery rate and categories of dromedary camel oocyte. Egypt J Basic Appl Physiol 2: 255-268.

El-Hatmi H, Levieux A, Levieux D (2006) Camel (Camelus dromedarius) immunoglobulin $\mathrm{G}, \alpha$-lactalbumin, serum albumin and lactoferrin in colostrum and milk during the early post partum period. J Dairy Res 73: 288-293.

El-Nahla AM, Kandil OM, Abdoon AS, Siam AA, Al-Monifi FA (2014) Effect of season and maturation time on oocyte competence and in vitro maturation of dromedary camel oocyte. Glob Vet 13: 39-46.

Farag IM, Girgis SM, Zowail ME, Abd-Allah SM, El-Nahas EM, El-Hafez MA (2012) Factors affecting in vitro maturation, yield and quality of camel (Camelus dromedarius) oocytes. Theriogenology Insight 2: 209-231.
Fujihara M, Comizzoli P, Wildt DE, Songsasen N (2012) Cat and dog primordial follicles enclosed in ovarian cortex sustain viability after in vitro culture on agarose gel in a protein-free medium. Reprod Domest Anim 47: 102-108.

Gordon I (2003) Laboratory production of cattle embryos. CABI, Wallingford, UK.

Javed A, Ghani MJ, Soufian S, Rezaei-Zarchi S, Kalantar SM (2010) An in vitro comparative study of growth media, sera and FSH effects on the growth and maturation of Syrian mice preantral follicles and enclosed-oocytes. Iran J Vet Res 11: 145-153.

Jianlin H (2011) Camelids. In: Pond WG, Bell AW, Ullrey DE, Baer CK (eds) Encyclopedia of Animal Science, 2nd ed., Taylor \& Francis, London, UK, pp 182-185.

Jin JI, Ghanem N, Kim SS, Choi BH, Ha AN, Lee KL, Sun DW, Lim HT, Lee JG, Kong IK (2016) Interaction of donor age, parity and repeated recovery of cumulus-oocyte complexes by ovum pick-up on in vitro embryo production and viability after transfer. Livest Sci 188: 43-47.

John FH (2011) Embryo transfer. In: Pond WG, Bell AW, Ullrey DE, Baer CK (eds) Encyclopedia of Animal Science, 2nd ed., Taylor Francis, London, UK, pp 336-338.

Kandil OM, El-Nahla AM, Siam AA, Abdoon AS, Al-Monifi FA, Mermillod P (2014) Effect of media on in vitro maturation rate of dromedary camel oocytes. Glob Vet 13: $159-165$.

Khalil WA (2005) Differences between farm animals in vitro matured and in vitro fertilized. MSc Anim Prod Dept, Fac Agric Mansoura Univ, Dakahlia, Egypt.

Khatir H, Anouassi A, Tibary A (2004) Production of dromedary (Camelus dromedarius) embryos by IVM and IVF and co-culture with oviductal or granulosa cells. Theriogenology 62: 1175-1185.

Khatir H, Anouassi A, Tibary A (2005) In vitro and in vivo developmental competence of dromedary (Camelus dromedarius) embryos produced in vitro using two culture systems (mKSOMaa and oviductal cells). Reprod Domest Anim 40: 245-249.

Khatir H, Anouassi A, Tibary A (2007) Effect of follicular size on in vitro developmental competence of oocytes and viability of embryos after transfer in the dromedary (Camelus dromedarius). Anim Reprod Sci 99: 413-42 0.

Khatir H, Anouassi A, Tibary A (2008) Effect of follicular fluid on the developmental competence of dromedary (Camelus dromedarius) oocytes obtained from small follicles. Theriogenology 70: 579.

Madison V, Avery B, Greve T (1992) Selection of immature bovine oocytes for developmental potential in vitro. Anim Reprod Sci 27: 1-11.

Nagy WMA (2014) In vitro maturation and fertilization of she-camel oocytes using different media and leptin hormone supplementation during breeding and non-breeding seasons. PhD Thesis. Anim Prod Dept, Fac Agric, Tanta Univ, Gharbia, Egypt.

Parrish JJ, Susko-Parrish JL, Leibfried-Rutledge ML, Critser ES, Eyestone WH, First NL (1986) Bovine in vitro fertilization with frozen-thawed semen. Theriogenology 25: 591-600.

Pavlok A, Lucas-Hahn A, Niemann H (1992) Fertilization and developmental competence of bovine oocytes derived from different categories of antral follicles. Mol Reprod Dev 31: 63-67. 
Ratto M, Gomez C, Wolter M, Berland M, Adams G (1999) Superstimulatory response and oocyte collection in alpacas. Proceedings of Congreso Mundial Sobre Camelidos, Cuzco, Perú, p 96.

Sansinena MJ, Taylor SA, Taylor PJ, Denniston RS, Godke RA (2003) Production of nuclear transfer llama (Lama glama) embryos from in vitro matured llama oocytes. Cloning Stem Cells 5: 191-198.

Shamiah SM (2004) Studies on in vitro fertilizing in Egyptian buffaloes. PhD Thesis, Anim Prod Dept, Fac Agric, Mansoura Univ, Dakahlia, Egypt.

Torner H, Heleil B, Alm H, Ghoneim IM, Srsen V, Kanitz W, Tuchscherer A, Fattouh EM (2003) Changes in cumulus-oocyte complexes of pregnant and non-pregnant camels (Camelus dromedarius) during maturation in vitro. Theriogenology 60: 977-987.

Trasorras V, Baca Castex C, Alonso A, Giuliano S, Santa Cruz R, Arraztoa C, Chaves G, Rodrtguez D, Neild D, Miragaya M (2014) First llama (Lama glama) pregnancy obtained after in vitro fertilization and in vitro culture of gametes from live animals. Anim Reprod Sci 148: 83-89.

Trasorras V, Giuliano S, Chaves G, Neild D, Aguero A, Carretero M, Pinto M, Baca Castex C, Alonso A, Rodrtguez D, Morrell JM, Miragaya M (2012) In vitro embryo production in llamas (Lama glama) from in vivo matured oocytes with raw semen processed with Androcoll-E using defined embryo culture media. Reprod Domest Anim 47: 562-567.

Wani NA, Billah M, Skidmore JA (2008) Studies on liquefaction and storage of ejaculated dromedary camel (Camelus dromedarius) semen. Anim Reprod Sci 109: 309-318.

Zeidan AEB, El Hammad M, Farouk MH, Shamiah SM, Ahmadi EAA, Nagy WMA, Gabr SA (2015) In-vitro maturation of camel oocytes using different media and sera. 66th Annual Meeting EAAP, 31 August - 4 September, Warsaw, Poland: Wageningen Academic Publisher, p 532. 